\title{
Macroeconomic effects of Mobile money: evidence from Uganda
}

\author{
Joseph Mawejje ${ }^{1 *}$ and Paul Lakuma ${ }^{2}$
}

\footnotetext{
* Correspondence: jmawejje@gmail. com

${ }^{1}$ The World Bank, Juba, South Sudan

Full list of author information is available at the end of the article
}

\begin{abstract}
This study examined the effects of mobile money - a recent innovation in Uganda's financial-sector landscape_-on aggregate economic activity and other macroeconomic variables. We first estimated the long-run mobile-money demand function using vector error correction (VEC) techniques, distinguishing between balances and transfers/ transactions. We then estimated the short-run effects of mobile money on selected macroeconomic variables using structural vector autoregressive (SVAR) methods. The results showed that mobile money had moderate positive effects on monetary aggregates, consumer price index, private-sector credit, and aggregate economic activity. Mobile money balances responded to changes in monetary policy instruments, signaling possible ameliorating effects for the conduct of monetary policy. Finally, the results showed that transactional motives related to mobile money had stronger macroeconomic effects than savings motives.
\end{abstract}

Keywords: Mobile money, Monetary policy, Inflation, Interest rates, Private-sector credit, Money demand, GDP, Uganda

\section{Introduction}

There has been growing enthusiasm for, and investigations of, the potential benefits of new financial innovations for poverty reduction and inclusive economic growth (e.g., Chibba 2009). Equally interesting are the implications of such financial innovations for the conduct of monetary policy (Ndirangu and Nyamongo 2015; Mehrotra and Yetman 2015). Mobile money is one such innovation that has revolutionized the financialsector landscape with regard to the way people save, make payments, and make transfers. There is growing interest in how mobile money might affect macroeconomic outcomes in developing countries (e.g., Nampewo et al. 2016; Aron et al. 2015).

The rapid expansion of mobile money has attracted much debate regarding its implications for the growth of the financial sector and the effectiveness of monetary policy. For example, mobile money can facilitate effective monetary policy to the extent that it improves financial inclusion. This is because households with access to formal financial markets can have complete access to instruments that facilitate borrowing and savings. Consequently, changes in policy interest rates have direct effects on intertemporal consumption and investment decisions. Lwanga and Adong (2016) found that having a registered mobile money account increased the likelihood of having some household savings in Uganda. This implies that in the presence of imperfections in financial

(c) The Author(s). 2019 Open Access This article is distributed under the terms of the Creative Commons Attribution 4.0 International License (http://creativecommons.org/licenses/by/4.0/), which permits unrestricted use, distribution, and reproduction in any medium, provided you give appropriate credit to the original author(s) and the source, provide a link to the Creative Commons license, and indicate if changes were made. 
markets, the increased adoption and use of mobile money could lead to increased formal savings.

There are concerns, however, that the proliferation of mobile transactions will change the landscape of traditional banking, carrying implications for financial-sector development, the conduct of monetary policy, and financial-sector regulation. Kamukama and Tumwine (2012) argued that the proliferation of mobile payments in Uganda could disadvantage commercial banks by weakening their liquidity.

Concerns have also been raised about the implications of mobile money for the conduct of monetary policy in Uganda. The adoption and use of mobile money imply a gradual substitution of real cash balances for bank deposits. This creates a larger money multiplier since all mobile money balances must be backed up by cash deposits in the escrow account of a partner commercial bank. Moreover, mobile money will obviously increase the velocity of money in circulation because it reduces the time and transaction costs of making retail payments. Indeed, innovations in the financial sector, including mobile money, have been shown to have statistically significant positive long-term effects on money velocity in Uganda (Nampewo and Opolot 2016).

At a 2015 conference convened by the International Growth Center in Kampala under the theme "Mobile Money and the Economy," the governor of the Bank of Uganda expressed his concerns thus:

\section{If more radical mobile banking business models are eventually developed in which mobile money becomes a substitute for demand deposits in banks, the ability of central banks to control interest rates could be undermined. This is because central banks control short-term interest rates by varying the liquidity available for commercial banks to meet their reserve requirements. But if mobile money eventually leads to a diminution of the role commercial banks play in the financial system, the interest rate transmission mechanism, which relies on movements in short-term interbank rates being transmitted along the yield curve to all other interest rates in the economy, will be weakened, which in turn will weaken the transmission mechanism of monetary policy. (Tumusiime-Mutebile 2015)}

Despite these concerns, there is insufficient research on the links between mobile money and its effects on the economy and the conduct of monetary policy. Nampewo et al. (2016) examined the role of mobile money in the supply of private-sector credit in Uganda. Similarly, Aron et al. (2015) examined the relevance of mobile money in inflationary processes. The present study provides novel evidence of the macroeconomic effects of mobile money in Uganda within a broader framework. In particular, this study examined the effects of mobile money on money stock, consumer price index, interest rates, private-sector credit, and gross economic activity. An important aspect of this study is that it establishes the implications of mobile money shocks for the conduct of monetary policy.

The results showed that mobile money has moderate positive effects on monetary aggregates, the consumer price index, and private-sector credit. Mobile money transactions are correlated with the composite index of economic activity. Mobile money deposits respond to changes in monetary policy instruments, signaling possible ameliorating effects for the conduct of monetary policy. 
The rest of this study is structured as follows: Section 2 provides the background for mobile money development in Uganda. Section 3 presents a brief survey of the literature. Section 4 introduces the analytical framework. The data and methods used in the analysis are discussed in section 5. The results are presented and discussed in section 6 . Finally, section 7 concludes the study and makes policy recommendations.

\section{Background}

The financial sector in Uganda has expanded rapidly over the last two decades. This growth was made possible by reforms that allowed for competition, particularly in the banking sector. However, despite these positive developments, access to formal financial services is still low: only $20 \%$ of the population has access to formal regulated financial intermediation services (World Bank 2017).

The introduction of mobile money in 2009 helped expand formal financial services to populations previously excluded. The adoption of mobile money has been rapid: a 2013 FINSCOPE survey showed that $56 \%$ of adults were using mobile money services, of which 34\% were registered users (EPRC 2013). This has been attributed to the increased demand for domestic remittances, the improved quality of existing financial services, and improved regulatory frameworks, among other reasons (Evans and Pirchio 2014). The number of registered mobile money accounts reached 21.6 million in 2016-more than half of Uganda's population of 35 million-and the number of formal commercial bank accounts was estimated at 5.2 million in 2016 (Bank of Uganda 2016).

By August 2016, the value of mobile money transactions had reached UGX 3.6 trillion, and balances on mobile money accounts had reached UGX 326 billion-the equivalent of $2.6 \%$ and $1.8 \%$ of M2 and M3, respectively (Fig. 1). An average of UGX 122 billion, or USD 34 million, is transferred through mobile money each day, mostly in small amounts averaging just over UGX 70,000 (USD 20) per transaction. However, there is scope for expanding access to mobile money services. A significant portion of Ugandans know about mobile money but do not use it. Close to $43 \%$ are considered "aware nonusers"; they are primarily poor, rural, and less educated (EPRC 2013).

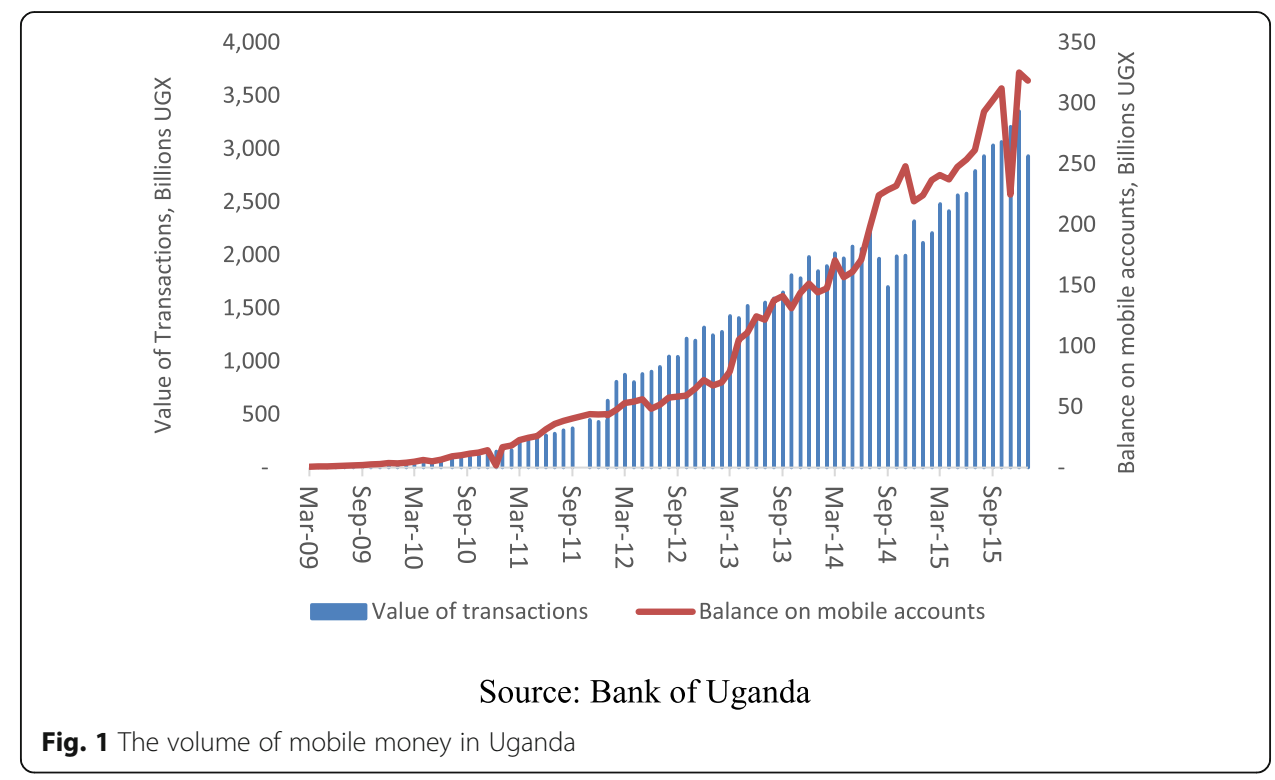


Currently, mobile money solutions are provided through four mobile network operators (MNOs): MTN Uganda, Airtel Uganda, Africell Uganda, and Uganda Telecom. A significant number of non-MNO mobile payments providers-such as M Cash, Ezee Money, PayWay, and Smart Money-also provide mobile money services (Bank of Uganda 2015). Mobile money service providers partner with a supervised financial institution (SFI) to provide mobile money services. These financial institutions hold escrow accounts that mirror the mobile money deposits held. Currently, four Ugandan financial institutionsStanbic Bank, Equity Bank, Centenary Bank, and Standard Chartered Bank-directly partner with mobile money service providers (Nampewo et al. 2016).

Individual mobile money service providers partner with financial institutions to effect mobile money services. While commercial banks have not been active mobile money providers in Uganda, the introduction of agency banking in 2016 could facilitate the entry of these institutions into mobile service provision. Uganda's business model follows the Smart Money of Smart Communication model in the Philippines, where an MNO collaborates with a commercial bank to offer mobile money services (MMS) (Ssonko 2011). A commercial bank's role is mainly to hold customers' funds in escrow accounts and release them on demand.

Mobile money services have evolved from person-to-person transfers and the storage of electronic value to include other services such as the following: checking bank balances; paying bills, utilities, salaries, social benefits, and taxes; making cross-border remittances; making transfers from a bank account to a mobile wallet; purchasing mobile phone airtime and data; extending microfinancing services; and facilitating village savings and loan accounts (VSLA), among other services (see Table 1).

Mobile money is also increasingly being used as a means to store value. As mentioned earlier, mobile money encourages savings by providing a secure and widespread mechanism to facilitate formal savings across socioeconomic boundaries. In Uganda,

Table 1 The evolution of mobile money in Uganda

\begin{tabular}{|c|c|}
\hline Date & Developments \\
\hline March 2009 & Mobile money is introduced in Uganda \\
\hline March 2009 & Domestic transfers/remittances P2P introduced \\
\hline July 2010 & Government payments of social benefits (G2P) introduced \\
\hline January 2010 & $\begin{array}{l}\text { Merchant payments - enabling SMEs and corporates to receive } \\
\text { payments P2B introduced }\end{array}$ \\
\hline June 2011 & Financial Consumer protection guidelines took effect \\
\hline October 2013 & Mobile money guidelines came into force \\
\hline April 2014 & Mobile banking; transfers from bank account to M-wallet commences \\
\hline June 2015 & $\begin{array}{l}\text { Bulk payments: salaries, wages B2P e.g. sugar, tea and construction } \\
\text { firms commence }\end{array}$ \\
\hline August 2015 & Cross border transfers enabled \\
\hline November 2015 & Statutory payments (Taxes) P2G commences \\
\hline March 2016 & $\begin{array}{l}\text { Group wallets for SACCOs and VSLA on the mobile money } \\
\text { platform }\end{array}$ \\
\hline June 2016 & International transfers enabled \\
\hline August 2016 & $\begin{array}{l}\text { Micro loans and savings program on the mobile money } \\
\text { platform Introduced }\end{array}$ \\
\hline January 2017 & Insurance service on the mobile money platform introduced \\
\hline
\end{tabular}

Source: Authors construction from key informant interviews with industry - January 2017 
mobile money platforms are integrated with participating banks to provide mobile savings products. Available evidence shows that individuals with mobile money accounts are 32\% more likely to have some savings than those without accounts (Lwanga and Adong 2016).

\section{Literature review}

There is a growing body of literature showing that mobile-phone-based technologies play a critical role in fostering financial inclusion and growth, particularly by reducing transaction costs and time constraints (Andrianaivo and Kpodar 2011). Relatedly, previous research has suggested that mobile money can help improve the incompleteness of financial markets with implications for macroeconomic stability (Adam and Walker 2015; Weil et al. 2012).

In recent years, there has been increased debate on the macroeconomic effects of the various facets of financial innovations, including mobile money. Sahay et al. (2015) examined the macroeconomic effects of financial inclusion with a special focus on economic growth, financial and economic stability, and inequality. First, they argued that financial inclusion increases economic growth-but only to a certain point, indicating that this relationship may be nonlinear. Second, they argued that unregulated credit expansion could be a basis for elevated financial risk. Lastly, they also argued that, in contrast to credit access, other forms of financial inclusion do not have adverse effects on financial stability.

Research investigating the effect of mobile money on financial-sector development is scarce and inconclusive. Earlier studies have suggested that mobile money could be detrimental to the ability of banks to mobilize savings and deposits (Kamukama and Tumwine 2012). However, such findings have been challenged by, among others, Nampewo et al. (2016), who used vector error correction modeling and Granger causality analysis to show that mobile money is an important driver of the private-sector credit supply via its effect on savings and deposit mobilization.

Ndirangu and Nyamongo (2015) used autoregressive distributed lag (ARDL) methods to investigate the effect of innovations in Kenya's financial sector on the stability of the money demand function. They found that the rapid pace of financial innovation during the period 1998-2013 did not distort the equilibrium of the money demand function.

Nampewo and Opolot (2016) examined the impact of financial innovations on money velocity in Uganda. They were primarily interested in determining whether money velocity was still important in the inflation-targeting regime. Using a cointegrated ARDL econometric approach, they found negative and positive effects of financial innovations on the velocity of money in the short and long runs, respectively.

Weil et al. (2012), focusing on the "new" phenomenon of mobile money in Kenya, were among the first to examine the implications of innovations in the financial sector for the conduct of monetary policy. While they documented the high velocity of mobile money transactions, they found that M-Pesa velocity was not any higher than the velocity of other monetary aggregates. They concluded that the implications of mobile money for the conduct of monetary policy were at best minimal.

To examine the macroeconomic effects of the rapid adoption of mobile money, Adam and Walker (2015) developed a Dynamic Stochastic General Equilibrium Model that clearly distinguished between households in rural and urban economies. In their model, mobile money serves as a remittance tool that enables urban households to 
send money to their rural counterparts, thus acting as insurance against unanticipated income fluctuations. Their results showed that mobile money might not undermine the conduct of monetary policy but, rather, improve macroeconomic stability, lending support to encouraging the spread of mobile money services.

There have been concerns that financial inclusion through the increased use of mobile money could lead to elevated inflationary risks. The potential impact of mobile money on inflation was first discussed by Simpasa and Gurara (2012), who argued that increased money velocity might propagate inflation, thus complicating the conduct of monetary policy. However, such claims were disputed by Aron et al. (2015), who, focusing on Uganda, developed inflation forecasting models using error correction techniques and did not find sufficient evidence to support the claim that mobile money is inflationary.

A growing strand of literature has examined the implications of financial inclusion for the design of monetary policy. Mehrotra and Yetman (2015) developed a theoretical framework to examine the effects of financial inclusion on maximizing monetary policy and found a positive relationship between financially included households and the ratio of output volatility to inflation volatility.

Financial inclusion could improve the effectiveness of monetary policy through its effect on financial-sector development. Opolot et al. (2015) argued that the efficacy of monetary policy and monetary policy transmission mechanisms depend on the strength of a country's "financial architecture." This implies that greater financial inclusion could improve the effectiveness of monetary policy to the extent that it improves the size, stability, and composition of the formal financial sector. Indeed, Mehrotra and Yetman (2015) argued that an increase in financial inclusion affects the effectiveness of monetary policy in two distinct ways. First, financial inclusion helps more households to smooth their consumption overtime, thus influencing basic monetary policy choices, including the target price index. Second, it encourages households to hold more noncash financial assets.

\section{Analytical framework}

Drawing on the literature, we developed a framework that aimed to link mobile money with macroeconomic indicators, including money stock, inflation, interest rates, private-sector credit, and aggregate economic activity. Figure 2 shows the analytical framework. Below, we map out the potential linkages between mobile money and these macroeconomic indicators.

\section{Mobile money and money stock}

There are two competing views regarding the likely impact of mobile money on money stock. The first view contends that financially excluded people might accumulate savings in the form of nonfinancial assets such as land, livestock, and jewelry (Mehrotra and Yetman 2015). For many households, mobile money could present opportunities to substitute such nonfinancial assets for electronic money, thus increasing the demand for broad money. Under such circumstances, we would expect mobile money to be positively associated with monetary aggregates. The second view contends that financial innovations might reduce the demand for money owing to improvements in transaction efficiency (Ndirangu and Nyamongo 2015). In particular, mobile money could 


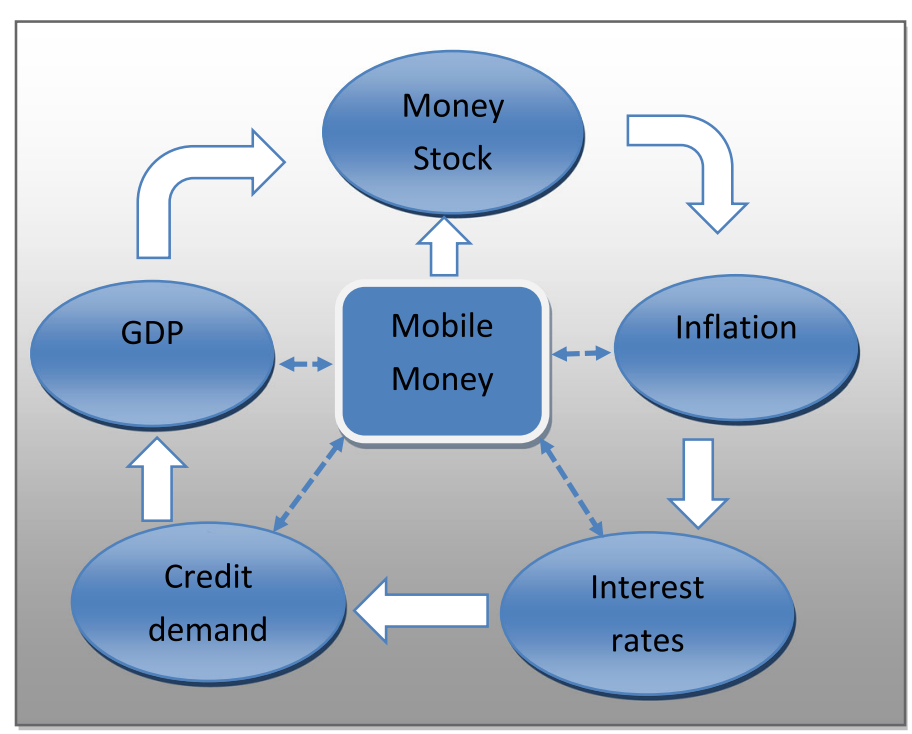

Source: Authors

Fig. 2 Analytical framework

reduce the transaction demand for money if it reduces the transaction costs and risks involved in dealing with cash, such as travel (to the bank), waiting times, and the risk of exposure to losses (e.g., via theft).

\section{Mobile money and inflation}

With regard to the potential relationship between mobile money and inflation, there are two alternative views. Mobile money could prove to be inflationary if it affects the velocity of money circulation without necessarily improving the levels of aggregate output. This is the view propagated by, among others, Simpasa and Gurara (2012). However, there could also be countervailing effects where mobile money improves productivity and economic efficiency, leading to lower transaction costs, higher output, and consequently a lower or nonexistent effect on inflation (Aron et al. 2015).

\section{Mobile money, interest rates, credit, and aggregate output}

Mobile money could affect interest rates through its effect on money demand and the supply of private-sector credit. If mobile money leads to an increase in money demand and inflation, then monetary authorities might respond by pursuing tight monetary policies leading to high interest rates. In addition, mobile money can affect private-sector credit. Essentially, mobile money deposits held in financial institutions' escrow accounts can be turned into loanable funds by financial institutions. Indeed, Nampewo et al. (2016) found that mobile money had emerged as an important determinant of privatesector credit growth in Uganda through its crucial role in savings and deposit mobilization. Finally, if mobile money leads to economic efficiency through reduced transaction costs, better resource allocation, and credit, then it follows that aggregate economic activity will be supported. In this regard, there is emerging evidence linking mobile money use to increased firm-level investments (Islam et al. 2017), agricultural 
and labor-market efficiency (Aker and Mbiti 2010; Sekabira and Qaim 2017), risk sharing (Mawejje, 2019; Riley 2018), and financial-sector development (Munyegera and Matsumoto 2018). These effects will likely have positive implications for growth (Andrianaivo and Kpodar 2011).

\section{Data and methods}

Data

We used monthly data spanning a period of 90 months between March 2009 and August 2016. This period is important because it relates to the introduction of mobile money services in Uganda. The data were collected from the Bank of Uganda and the Uganda Bureau of Statistics. In particular, this study used the natural logarithm of mobile money balances (LMMB), the natural logarithm of money stock (LM2), the natural logarithm of consumer price index (LCPI), treasury bill rates (TBR), the natural logarithm of private-sector credit demand (LPSC), and aggregate economic activity. The Uganda Bureau of Statistics only compiles quarterly GDP data. We therefore used the natural logarithm of the composite index of economic activity (LCIEA) as a proxy for real economic activity.

The CIEA is highly correlated with quarterly GDP and is a useful leading indicator for the short-term analysis and forecasting of economic activity (Anguyo 2011). Ideally, we should have used the central bank rate (CBR) as an indicator of monetary policy changes. However, the CBR was only introduced in June 2011, and using it would have led to a significant loss of data points and degrees of freedom. We thus used the 91-day treasury bill rate, which is available on a monthly basis and is well correlated with the CBR. Table 2 provides the descriptive statistics of the data.

Before proceeding with the analysis, it was important to establish the time-series properties of the data. We employed the Dickey-Fuller Generalized Least Squares (DFGLS) procedure of Elliott et al. (1996) to test for unit roots in the data-generating process. The DFGLS procedure was preferred because of its power and superior performance, especially with relatively small samples. In carrying out the unit root tests, we considered both trends and intercepts in the data-generating processes. The unit root test results (Table 3) showed that all variables had unit roots and therefore followed I (1) processes.

\section{Vector error-correction methods}

We used vector error-correction methods to investigate the dynamic linkages between mobile money balances and money demand. A major advantage of using vector error correction methods is that they provide convenient ways to deal with nonstationarity in

Table 2 Descriptive statistics

\begin{tabular}{lllllll}
\hline Variable & Obs & Mean & Median & Std Dev & Min & Max \\
\hline LMMB & 90 & 3.887 & 4.193 & 1.731 & -0.509 & 5.808 \\
LMMVT & 90 & 6.242 & 7.114 & 1.964 & -0.716 & 8.207 \\
LM2 & 90 & 9.024 & 9.060 & 0.269 & 8.437 & 9.417 \\
LCPI & 90 & 4.850 & 4.895 & 0.166 & 4.533 & 5.069 \\
TBR & 90 & 10.822 & 9.596 & 4.366 & 3.696 & 20.282 \\
LPSC & 90 & 8.894 & 8.980 & 0.356 & 8.176 & 9.367 \\
LCIEA & 90 & 5.066 & 5.086 & 0.132 & 4.847 & 5.285 \\
\hline
\end{tabular}


Table 3 Stationarity tests

\begin{tabular}{llll}
\hline Variable & \multicolumn{2}{c}{ DFGLS Unit Roost Test Statics } & Order of \\
\cline { 2 - 4 } & In levels & In first differences & Integration \\
\hline LMMB & -1.065 & $-10.172^{* * *}$ & $\mid(1)$ \\
LMMVT & -0.873 & $-11.961^{* * *}$ & $\mid(1)$ \\
LM2 & -1.558 & $-3.471^{* * *}$ & $\mid(1)$ \\
LCPI & -1.322 & $-6.322^{* * *}$ & $\mid(1)$ \\
TBR & -2.233 & $-5.451^{* * *}$ & $\mid(1)$ \\
LPSC & -0.505 & $-8.866^{* * *}$ & $\mid(1)$ \\
LCIEA & -2.462 & $-6.314^{* * *}$ & $\mid(1)$ \\
\hline
\end{tabular}

Notes: ${ }^{* * *}$ indicate significance of the Elliott-Rothenberg-Stock DFGLS test statistic at the $1 \%$ level

data series without the loss of critical information that is inherent in data-generating processes in levels. In particular, when the variables under consideration are firstdifference stationary, vector error-correction frameworks can be used in a way that avoids loss of information by modeling the linear combinations of the data in levels.

Assume a k-dimensional vector autoregressive representation that can be expressed as in eq. 1) below:

$$
Z_{t}=\mathrm{B}(L) \mathrm{Z}_{t}+\mu_{t}
$$

where $\mathrm{Zt}^{\prime}=\mathrm{Z} 1 t, \mathrm{Z} 2 t, \ldots, \mathrm{Zkt}$ is a vector of endogenous variables; $\mathrm{B}^{\prime}=(\mathrm{B} 1, \mathrm{~B} 2, \ldots, \mathrm{B} p)$ represents a kxk matrix of coefficients; $\mathrm{L}$ is the lag operator; $\mu t \sim i i \mathrm{~d} N(0, \delta)$ is a kdimensional vector of Gaussian errors, with $\mathrm{E}(\mu t)=0$; and $\mathrm{t}=1,2, \ldots, T$ indexes the time periods.

Equation (1) may be expressed in an error-correction formulation, combining both the levels and the first differences of the data series, as shown in Eq. (2). Importantly, the multicollinearity problem often present in time series data is reduced by this transformation:

$$
{ } Z_{t}=\alpha \beta^{\prime} Z_{t-1}+\sum_{i=1}^{k-1} \Gamma_{i} \Delta Z_{t-1}+\mu_{t}
$$

where $\mathrm{Z} t$ is a vector of endogenous variables of interest; $\alpha \beta^{\prime}$ and $\Gamma i$ are the long-run and short-run coefficients to be estimated by the Johansen (1988) procedure; and $i=1$, ..., $k-1$ represents the optimal lags included in the system computed using the appropriate lag selection criteria. If the variables in $\mathrm{Z} t$ are first-difference stationary or firstorder integrated (i.e., I (1)), then the long-run matrix $\alpha \beta^{\prime}$ can be said to be of reduced rank, where $\alpha$ represents the adjustment parameters and $\beta$ is the matrix of long-run coefficients.

To obtain the long-run equilibrium, we proceeded as follows: we investigated the time-series properties of the data series. It is important that all variables are difference stationary. We then estimated a vector autoregressive (VAR) model and obtained the appropriate lag length. We tested for cointegration and determined the number of cointegrating relationships in the long-run matrices $\alpha \beta^{\prime} Z t-1$ following Johansen's procedure. We then estimated the unrestricted cointegrating relations in the vector error 
correction model to determine the equilibrium long-run relationship. Finally, we tested for model stability.

\section{Structural vector autoregressive model}

The structural vector autoregressive (SVAR) approach allows for contemporaneous feedback between variables while imposing the minimal structural restrictions on the model (Kim \& Roubini 2000). In a VAR framework, all variables are endogenous, and as a reduced-form representation of a large class of structural models, an SVAR model offers both empirical predictability and a link between data and theory using the assumptions underlying the structure of the economy (Hamilton, 1994). Thus, we could formulate the structural autoregressive model as shown in Eq. (3):

$$
A Z_{t}=\gamma+\sum_{i=1}^{p} A_{i} Z_{t-1}+B \mu_{t}
$$

where $\mathrm{Z} t$ is an $n x 1$ vector of endogenous variables; $A$ and $B$ are invertible $n x n$ matrices capturing contemporaneous relations among the variables in vector $Z t ; y$ is a vector of constants; A $i$ are $n x n$ matrices of unknown parameters on lagged values of $\mathrm{Zt}$ to be estimated; $\mu$ is an $n x 1$ vector of uncorrelated structural innovations or shocks corresponding to each element of Zt with covariance matrix $\mathrm{E}\left|u t u t^{\prime}\right|=\Sigma \varepsilon$ for $t=1,2$, $3, \ldots, T$; and $n$ is the number of variables in the system. A reduced-form representation of Eq. (3), generated by multiplying through both sides of the equation by the inverse of matrix $A$, is shown in eq. (4):

$$
Z_{t}=\varphi+\sum_{i=1}^{p} \phi_{i} Z_{t-1}+\varepsilon_{t}
$$

where

$$
\varphi=A^{-1} \gamma ; \phi_{i}=A^{-1} A_{i} \text {; and } \varepsilon_{t}=A^{-1} B \mu_{t} \text {. }
$$

In the formulation given in Eq. (3), structural shocks are orthogonal to each other. We used the Cholesky decomposition of the variance-covariance matrix of the reduced VAR residuals, $\Sigma \varepsilon$, to generate the structural shocks. To identify $A$ and $B$ and thus generate impulse response functions, at least $2 \mathrm{n} 2-\mathrm{n}(\mathrm{n}+1) / 2$ additional restrictions are required in addition to $n$ normalization restrictions for the system to be just identified (Lutkepohl 2005).

We adopted a recursive identifying structure whereby a priori restrictions were imposed on contemporaneous interactions among $\mathrm{Z} t$ variables to identify the coefficient matrix $A$. Thereafter, the dynamic impact of $\mu t$ could be traced on the path of any element in $Z$. In this specification, mobile money balances (LMMB), money stock (LM2), consumer price index (LCPI), treasury bill rates (TBR), private-sector credit demand (LPSC), and aggregate economic activity (LGDP) were entered as endogenous variables. All variables, except treasury bill rates, were expressed in natural logarithms.

The order of the variables is important in an SVAR model because it defines the transmission of structural shocks in a way that mimics economic theory. Following our analytical framework, we assumed that mobile money balances are only affected by own innovations; money stock is only affected by mobile money; the consumer price 
index is affected by money stock and mobile money; treasury bill rates are influenced by the consumer price index, money stock, and mobile money; private-sector credit is influenced by treasury bill rates, consumer price index, money stock, and mobile money; and GDP is affected by all endogenous variables included in the model. The ordering of the variables is expressed in the following system of equations:

$$
\begin{aligned}
& \varepsilon_{t}^{L M M B}=\mu_{t}^{L M M B} \\
& \varepsilon_{t}^{L M 2}=a_{21} \mu_{t}^{L M M B}+\mu_{t}^{L M 2} \\
& \varepsilon_{t}^{L C P I}=a_{31} \mu_{t}^{L M M B}+a_{32} \mu_{t}^{L M M B}+\mu_{t}^{L C P I} \\
& \varepsilon_{t}^{T B 91}=a_{41} \mu_{t}^{L M M B}+a_{42} \mu_{t}^{L M 2}+a_{43} \mu_{t}^{L C P I}+\mu_{t}^{T B R} \\
& \varepsilon_{t}^{L P S C}=a_{51} \mu_{t}^{L M M B}+a_{52} \mu_{t}^{L M 2}+a_{53} \mu_{t}^{L C P I}+a_{54} \mu_{t}^{T B R}+\mu_{t}^{L P S C} \\
& \varepsilon_{t}^{L C I E A}=a_{61} \mu_{t}^{L M M B}+a_{62} \mu_{t}^{L M 2}+a_{63} \mu_{t}^{L C P I}+a_{64} \mu_{t}^{T B R}+a_{65} \mu_{t}^{L P S C}+\mu_{t}^{L C I E A}
\end{aligned}
$$

\section{Results and discussion}

\section{Mobile money demand functions}

In estimating mobile money demand functions, we proceeded as follows. First, we estimated the traditional Keynesian representation that only includes three variables: the natural logarithm of real mobile money balances (LRMMB), the natural logarithm of the composite index of economic activity (LCIEA), and treasury bill rates (TBR). We then reestimated the model using the real mobile money value of transactions/transfers (LRMMVT).

In estimating these functions, we applied one lag for each variable as indicated by the Schwartz information criterion, as shown in Table 4. The Hannan-Quinn information criterion indicated an optimal lag length of two, and LR, FPE, and AIC all indicated lag lengths of eight; however, we did not use them because of issues with degrees of freedom given the relatively small sample we had to work with.

The Johansen cointegration procedure indicated that there was at least one cointegrating relationship that explained an equilibrium long-run relationship in the money demand equation (Table 5). In particular, the maximum eigenvalue was greater than the associated critical value, suggesting that the null hypothesis of "no cointegration" is rejected in favor of the alternative hypothesis for one rank at the $1 \%$ level of significance.

Taking the Keynes (1936) postulation as a starting point for our analysis, we estimated the demand for real mobile money balances (LRMMB) as a function of the composite index of economic activity (LCIEA) and the opportunity cost of holding money, taking the treasury bill rate (TBR) as the policy instrument, such that 
Table 4 Lag length selection in the money demand function

\begin{tabular}{lllllll}
\hline Lag & LogL & LR & FPE & AIC & SC & HQ \\
\hline 0 & -42.650 & NA & 0.001 & 1.113 & 1.201 & 1.148 \\
1 & 304.511 & 660.453 & $0.60 \mathrm{e}-07$ & -7.134 & $-6.782^{*}$ & -6.993 \\
2 & 319.476 & 27.374 & $1.39 \mathrm{e}-07$ & -7.279 & -6.663 & $-7.032^{*}$ \\
3 & 329.425 & 17.472 & $1.36 \mathrm{e}-07$ & -7.303 & -6.422 & -6.949 \\
4 & 341.078 & 19.610 & $1.28 \mathrm{e}-07$ & -7.367 & -6.223 & -6.908 \\
5 & 344.111 & 4.882 & $1.49 \mathrm{e}-07$ & -7.222 & -5.813 & -6.656 \\
6 & 359.556 & 23.733 & $1.28 \mathrm{e}-07$ & -7.379 & -5.706 & -6.707 \\
7 & 365.336 & 8.457 & $1.41 \mathrm{e}-07$ & -7.301 & -5.363 & -6.523 \\
8 & 380.123 & $20.557^{*}$ & $1.25 \mathrm{e}-07^{*}$ & $-7.442^{*}$ & -5.240 & -6.558 \\
\hline
\end{tabular}

Note: ${ }^{*}$ Lag order selected by the criterion at $5 \%$ level

$$
L R M M B_{t}=f\left(T B R_{t}, L C I E A_{t}\right)
$$

where $f T B R^{\prime}<0$ and $f$ LCIEA' $>0$ imply that real mobile money demand was reduced in the policy (interest) rates and increased in economic activity. We then examined the long-run transaction demand for mobile money. The idea was to examine how mobile money is related to aggregate economic activity and interest rates, and not necessarily to arrive at the true mobile money demand function for Uganda. Consequently, the mobile money transaction demand function we estimated took the following form:

$$
\operatorname{LRMMVT}_{t}=f\left(\mathrm{TBR}_{t}, \mathrm{LCIEA}_{t}\right)
$$

Table 6 presents the results for the long-run mobile money demand functions. Panel (1) shows the demand function for mobile money balances (savings), and panel (2) presents the demand function for mobile money transactions (transfers). The results indicated that, as expected, both real mobile money balances and the volume of transactions were negatively affected by interest rates and positively associated with economic activity. Importantly, the coefficient of the natural logarithm of the composite index of economic activity was larger in the mobile money transactions model, signifying that shocks to economic activity had larger corresponding effects on mobile money transactions than on mobile money balances.

The error correction terms for the two models in Table 6, -0.059 and -0.099 , are statistically different from zero, implying that $6 \%$ and $10 \%$, respectively, of disequilibria in the long-run relationships in panels (1) and (2) were corrected in the following time period. The inverse roots of the characteristic polynomial indicated that both models were stable, seeing that all roots located within the unit circle. Further diagnostic tests revealed that the models were well specified and suffered no autocorrelation.

\section{Macroeconomic effects of mobile money}

To evaluate the short-term macroeconomic effects of mobile money, we estimated the SVAR model presented in section 4.3. In the SVAR, we included a selection of macroeconomic variables that included the natural logarithms of nominal mobile money 
Table 5 Cointegration test based on the trace and max tests

\begin{tabular}{lll}
\hline $\mathrm{H}_{0}$ & Trace test & Max test \\
\hline$r=0$ & $32.435^{* *}$ & $17.826^{* *}$ \\
$r=1$ & 15.166 & 12.256 \\
\hline
\end{tabular}

** denotes rejection of the hypothesis at the $5 \%$ level

balances (LMMB), money stock (LM2), consumer price index (LCPI), treasury bill rates (TBR), nominal private-sector credit (LPSC), and the composite index of economic activity (LCIEA), in that order. As discussed earlier, the SVAR identifies structural shocks in the VAR system by imposing restrictions that mimic economic theory. The SVAR we estimated assumed the variables were related in a recursive manner in the order explained above.

In estimating SVAR, we applied one lag for each variable in the underlying VAR, as indicated by the Schwartz and Hannan-Quin information criteria (Table 7). While the FPE and AIC indicated a lag length of eight, and the LR indicated an optimal lag length of 7, we opted to work with a shorter lag length because of concerns about the loss of degrees of freedom and efficiency, given the relatively small sample size.

The results shown in Fig. 3 show the short-run effects of mobile money on the set of macroeconomic variables. The blue lines show the reaction of a given variable due to a Cholesky one standard deviation innovation in mobile money balances. The red lines show the confidence bands around the estimated impulse.

The effect of a positive mobile shock on the consumer price index is similar to that of the money stock. A one standard deviation positive shock in mobile money balances initially results in a decline in the consumer price index during the first 6 months, which thereafter gradually rises, becoming significant between the eighteenth and twenty-fourth months. While these results do not concur with Aron et al. (2015), who found modest if insignificant effects of mobile money on inflation processes, they are certainly in line with other findings showing that the macroeconomic effects of mobile money are at best modest. With regard to the effect on money stock, a one standard deviation positive shock in mobile money balances results in an increase in money stock in the first 8 months, before the effect starts to decline. However, this result is not statistically significant and projects weak mobile money effects on money demand. This result is consistent with the theory that mobile money may lead to the liquidation of nonfinancial assets, which results in a larger money stock in the short run, especially in developing countries like Uganda that are still at lower levels of financial inclusion.

Table 6 The long-run mobile money demand model

\begin{tabular}{lll}
\hline & $(1)$ & $(2)$ \\
\hline LRMMB & 1.000 & 1.000 \\
LRMMVT & & $5.495[6.097]^{* * *}$ \\
LCIEA & $4.367[2.615]^{* * *}$ & $-0.059[-2.304]^{* * *}$ \\
TBR & $-0.089[-1.813]^{*}$ & 2.674 \\
Constant & 17.486 & $-0.099[-6.751]^{* * *}$ \\
Error correction & $-0.059[-6.169]^{* * *}$ &
\end{tabular}

Notes: 1. Tabulated are the coefficients, $t$-statistics are in square brackets. 2. Significance levels: $* * *=$ significant at the $1 \%$ level, ${ }^{*}=$ significant at the $10 \%$ level 
Table 7 Lag-order selection criteria

\begin{tabular}{lllllll}
\hline Lag & LogL & LR & FPE & AIC & SC & HQ \\
\hline 0 & 153.512 & NA & $1.84 \mathrm{e}-08$ & -3.622 & -3.475 & -3.563 \\
1 & 684.661 & 984.567 & $8.01 \mathrm{e}-14$ & -15.967 & $-15.086^{*}$ & $-15.613^{*}$ \\
2 & 717.211 & 56.366 & $6.71 \mathrm{e}-14$ & -16.151 & -14.537 & -15.503 \\
3 & 744.525 & 43.970 & $6.45 \mathrm{e}-14$ & -16.207 & -13.859 & -15.265 \\
4 & 772.055 & 40.958 & $6.27 \mathrm{e}-14$ & -16.269 & -13.187 & -15.032 \\
5 & 796.451 & 33.322 & $6.72 \mathrm{e}-14$ & -16.254 & -12.439 & -14.723 \\
6 & 837.861 & 51.510 & $4.90 \mathrm{e}-14$ & -16.655 & -12.105 & -14.828 \\
7 & 893.755 & $62.710^{*}$ & $2.61 \mathrm{e}-14$ & -17.408 & -12.125 & -15.287 \\
8 & 927.189 & 33.433 & $2.52 \mathrm{e}-14^{*}$ & $-17.614^{*}$ & -11.597 & -15.198 \\
\hline
\end{tabular}

According to Simpasa and Gurara (2012), who first discussed the possible inflationary effects of mobile money, the inflationary effect is probable if, as evidenced by our results, mobile money does not lead to an improvement in economic activity (GDP). If mobile money greatly serves to facilitate transactions, and not the creation of added value, then it might serve to increase money velocity, as discussed by Nampewo and Opolot (2016).

A positive shock in mobile money is associated with a reduction in treasury bill rates. A one standard deviation positive shock in mobile money balances results in a decline in the treasury bill rates within the first 4 months. However, this effect is modest and not statistically significant.

The effect of a positive mobile money shock on private-sector credit is positive and statistically significant between the third and thirteenth months. The impact of a mobile money shock on private-sector credit is at its maximum during the twelfth month. These findings are consistent with Nampewo et al. (2016), who found that mobile money was associated with the supply of credit by commercial banks. Indeed, this finding is also consistent with the negative impact of mobile money on treasury bill rates.

To corroborate the findings, we reestimated the SVAR using the natural logarithm of the value of mobile money transactions/transfers. The results shown in Fig. 4 were largely unchanged, aside from larger and statistically significant effects on money demand, interest rates, and the index of economic activity. This indicates that the transactional value of mobile money has stronger macroeconomic effects than its savings value.

\section{Mobile money and the conduct of monetary policy}

With regard to the implications of mobile money for the conduct of monetary policy, we evaluated the responses of mobile money balances and other key macroeconomic variables to policy rate shocks. The results presented in Fig. 5 show that mobile money balances respond to changes in the policy rate. Specifically, a one standard deviation positive shock in the monetary policy rate results in a decline in mobile money balances. The impact of treasury bill rates on mobile money balances reaches its maximum between the twelfth and fourteenth months. These findings alleviate any fears that the development of mobile money technologies might weaken monetary policy transmission mechanisms. Indeed, these results are consistent with Adam and Walker (2015), who used DSGE 


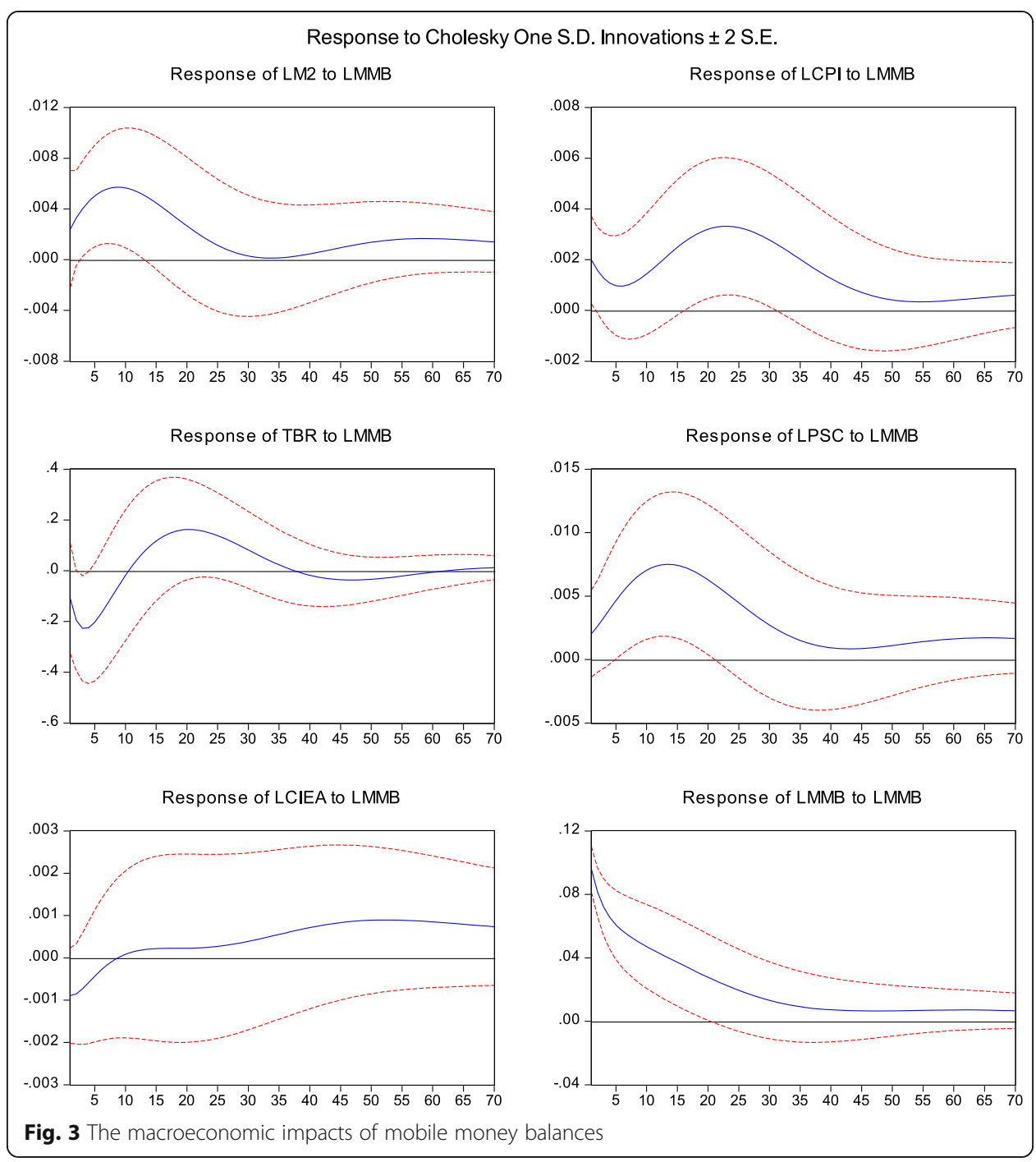

methods to show that mobile money technology does not undermine monetary policy transmission but, instead, increases macroeconomic stability.

Again, as in the previous subsection, we reestimated the SVAR model using the logarithm of the value of mobile money transactions to examine the differentiated implications for the conduct of monetary policy. The results shown in Fig. 6 were largely unchanged, except that mobile money transactions were not statistically significantly responsive to shocks in the policy rate. This implies that improvements in the conduct of monetary policy are stronger for "savings" as opposed to "transactions" in mobile money motives.

The effect of treasury bill rate shocks on the rest of the macroeconomic variables conformed to a priori expectations. A one standard deviation shock in treasury bill rates results in a decline in the demand for money, and the effect is statistically significant within 18 months after the shock. High interest rates incentivize economic agents to substitute liquid assets for financial assets, thus reducing the demand for money. This is consistent with the Keynes (1936) postulation regarding the money demand function. 


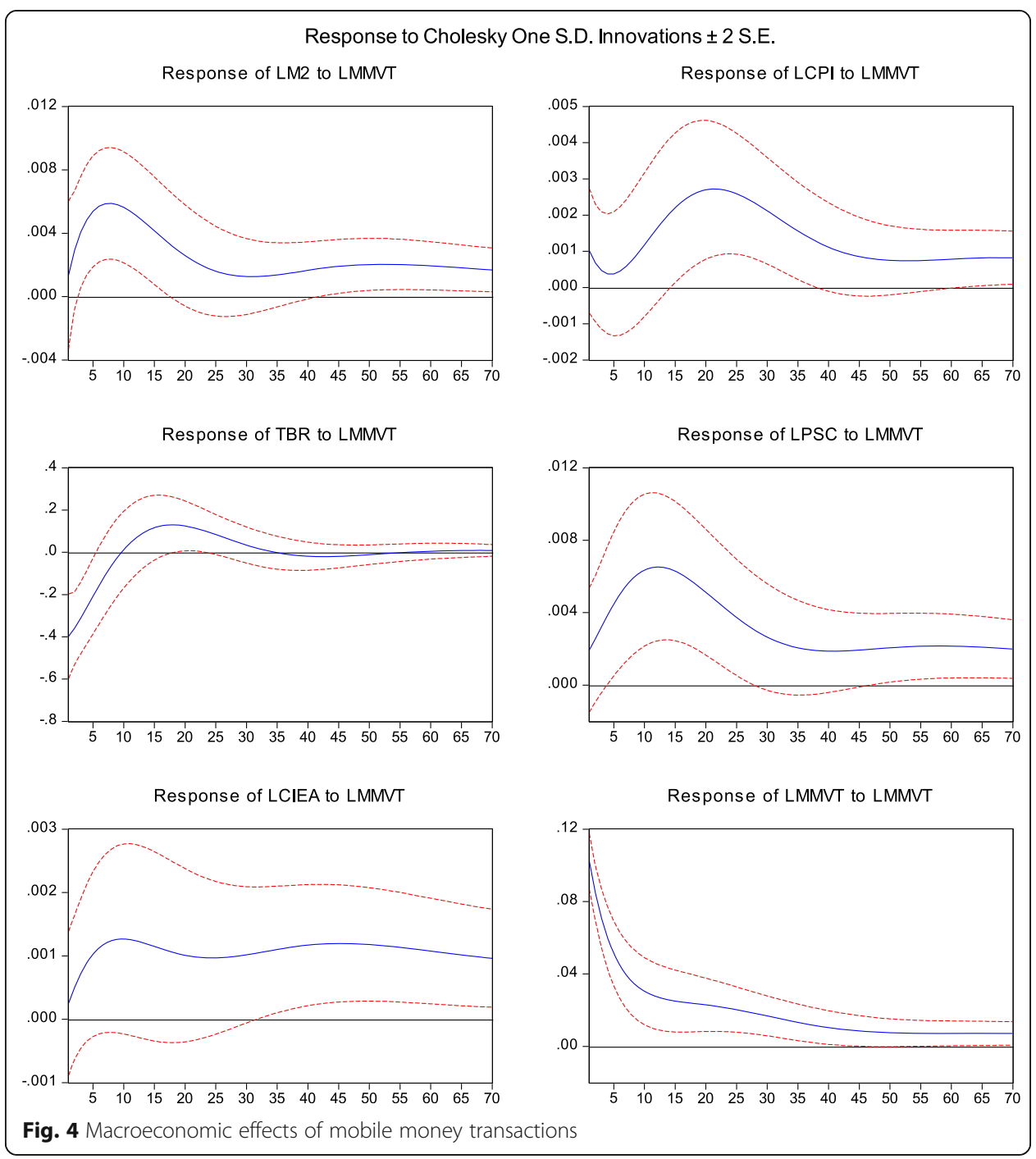

An increase in treasury bill rates initially results in an increase in consumer price, albeit insignificantly, within the first 6 months before the CPI starts to decline significantly. The maximum impact of a monetary policy shock on the CPI is realized within 21 months, before becoming insignificant within 34 months. This finding suggests that monetary policy effects on inflation take time to reach their full effects.

A positive shock in treasury bill rates affects GDP and private-sector credit. The impact of a treasury bill shock on private-sector credit is at its maximum eighteen months after the shock. Likewise, the effect of a shock in treasury bill rates on gross domestic product is at its maximum sixteen months after the shock. These results are consistent with Nampewo et al. (2016), who found that interest rate shocks affected aggregate production, with potential implications for the demand for private-sector credit.

\section{Conclusion and policy options}

Access to quality and affordable financial products remains a key challenge in the growth and competitiveness of Uganda's economy. Developing innovative financial products, including those on mobile platforms, has been at the forefront of improving 


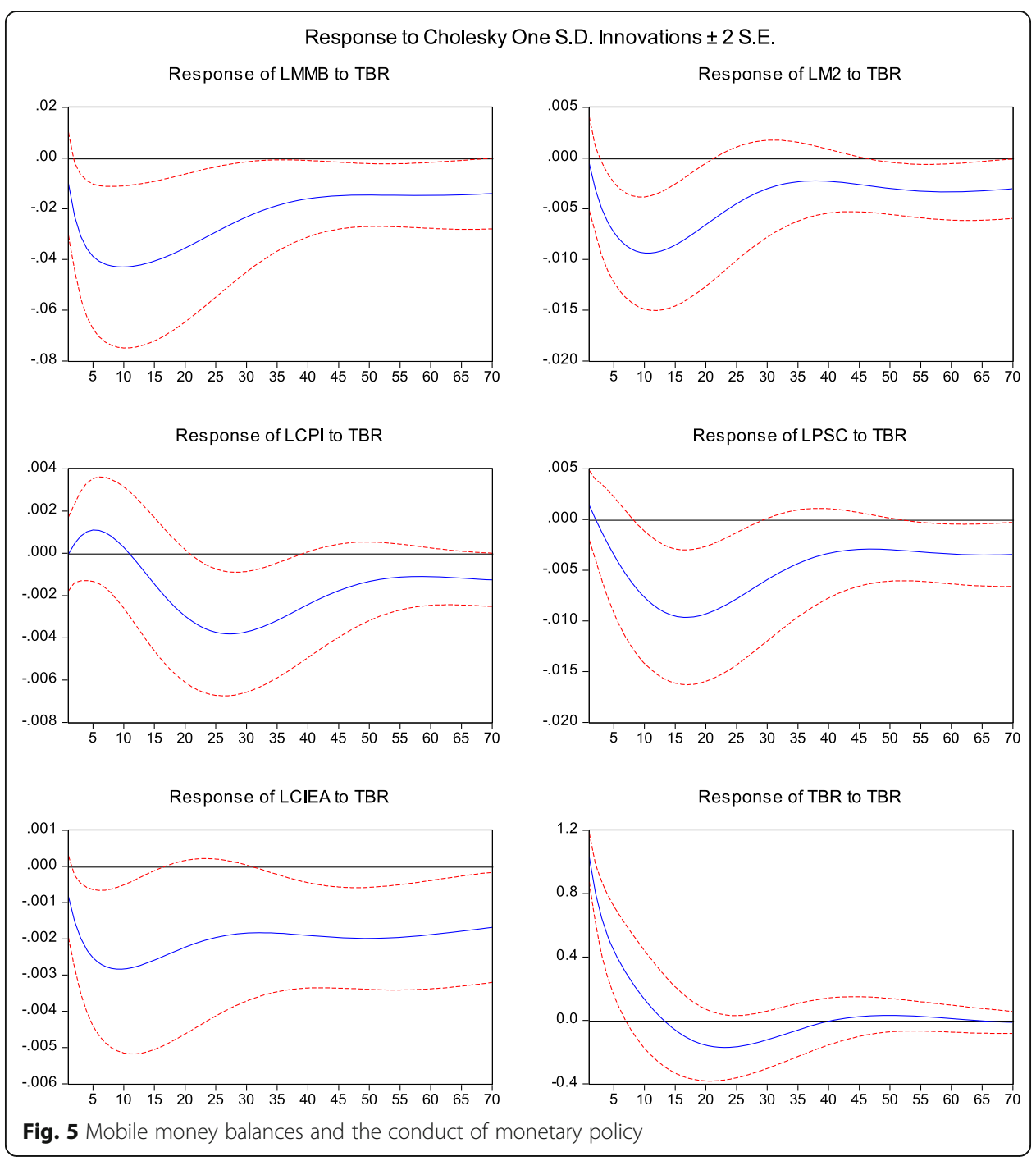

financial inclusion outcomes across a number of African countries. Uganda is one of the countries where access to and the use of mobile money have expanded rapidly in recent years.

Despite the known benefits of mobile money with regard to easing commerce, savings, and risk management, there are concerns that it might undermine financial-sector stability and alter the landscape for the conduct of monetary policy. This study set out to examine the macroeconomic impacts of mobile money. In particular, we investigated the responsiveness of key macroeconomic variables (e.g., interest rates, money stock, the consumer price index, and private-sector credit) to changes in mobile money balances. An important aspect of this study is the consideration of the implications of mobile money for the conduct of monetary policy. In particular, we wanted to know if mobile money balances respond to short-term changes in central bank policy rates.

Our econometric analysis was based on two separate but complementary approaches: vector error correction (VEC) and structural vector autoregressive (SVAR) methods. First, VEC methods showed that mobile money is increasing in gross economic activity and reducing in interest rates. The effect of gross economic activity is stronger for the 


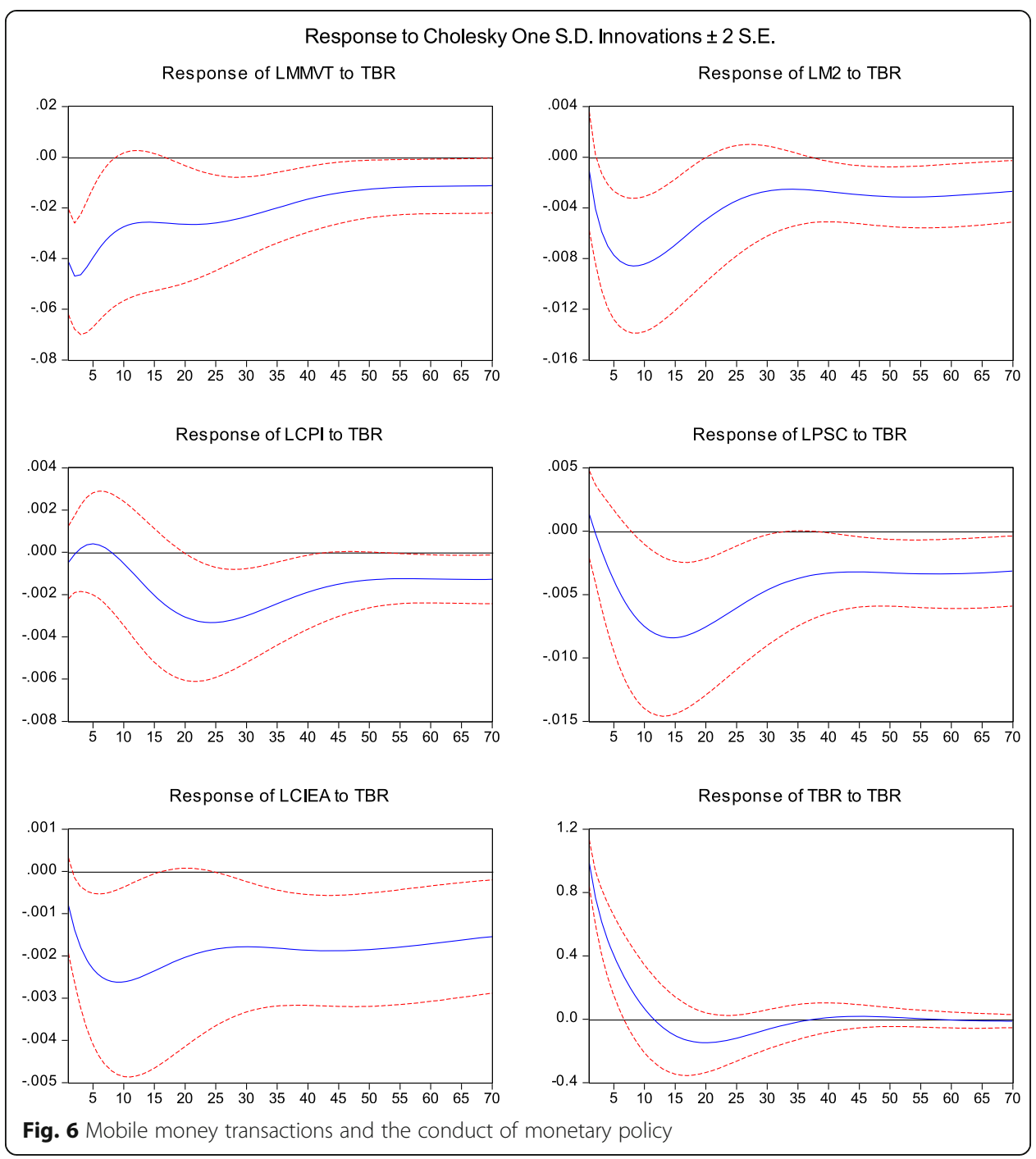

transaction value of money. Second, SVAR models showed moderate short-term macroeconomic effects of mobile money. In particular, positive shocks to mobile money balances were found to be positively associated with higher consumer price indexes and private-sector credit. The effect on other macroeconomic variables was invariably modest. However, shocks to mobile money transfers exhibited larger effects on money demand and gross economic activity. In addition, the ameliorating effects of mobile money in the conduct of monetary policy were stronger for "savings" as opposed to "transaction" mobile money motives.

These results suggest that 1) mobile money has helped households to substitute liquid and other lumpy assets for financial assets, 2) mobile money has modest macroeconomic impacts, and 3) mobile money has the potential to improve the effectiveness of the conduct of monetary policy. These results provide additional evidence for policy makers to continue supporting the growth of mobile money platforms. In particular, policy makers should provide a policy and regulatory framework through which mobile money balances can become interest-bearing assets. This will further strengthen the monetary policy transmission mechanism because economic agents will be able to 
more directly respond to changes in the policy rate. Exploring mechanisms through which mobile money can more ably contribute to growth is an important area for further investigation.

These results, however, should be interpreted with caution given the relatively short time span of the analysis. In addition, given that mobile money adoption is still developing at breakneck speed, there could be nonlinearities that might mask its full effects. Finally, ongoing innovations in mobile money markets-such as the introduction of microcredit facilities-might alter the established macroeconomic consequences of mobile money.

\section{Abbreviations}

ARDL: Autoregressive Distributed Lag; B2P: Business-to-Person; CBR: Central Bank Rate; CIEA: Composite Index of Economic Activity; CPI: Consumer Price Index; DFGLS: Dickey-Fuller Generalised Least Squares; G2P: Government-toPerson; GDP: Gross Domestic Product; MMB: Mobile Money Balances; MMS: Mobile Money Service; MMVT: Mobile Money Value of Transactions; MNO: Mobile Network Operator; P2G: Person-to-Government; P2P: Person-to-Person; PSC: Private Sector Credit; SACCO: Savings and Credit Cooperative; SFI: Supervised Financial Institution; SVAR: Structural Vector Autoregressive; TBR: Treasury Bill Rate; UGX: Uganda Shillings; USD: United States Dollars; VAR: Vector Autoregressive; VEC: Vector Error Correction; VSLA: Village Savings and Loan Association

\section{Acknowledgements}

This study benefited from insightful discussions and comments from colleagues at the Economic Policy Research Centre, Makerere University, and three anonymous peer reviewers. All errors are omissions are ours.

\section{Authors' contributions}

JM conceptualized the study, contributed the data analysis and parts of the literature review. PL contributed the background, parts of the literature review, and refined the draft paper. All authors read and approved the final manuscript.

\section{Funding}

This research did not benefit from any funding body.

\section{Availability of data and materials}

All data used in the study are available from the Bank of Uganda at: https:/www.bou.or.ug/bou/rates_statistics/ statistics.html

\section{Competing interests}

The authors declare that they have no competing interests.

\section{Author details}

${ }^{1}$ The World Bank, Juba, South Sudan. ${ }^{2}$ Economic Policy Research Centre, Makerere University, Kampala, Uganda.

Received: 20 October 2017 Accepted: 26 May 2019

Published online: 11 June 2019

\section{References}

Adam C and Walker SEJ (2015) Mobile money and monetary policy in east African countries, University of Oxford. Oxford: United Kingdom

Aker JC, Mbiti IM (2010) Mobile phones and economic development in Africa. J Econ Perspect 24(3):207-232

Andrianaivo M, Kpodar K (2011) ICT, financial inclusion, and growth: evidence from African countries, IMF working paper WP/ 11/73. International Monetary Fund, Washington DC

Anguyo FL (2011) A model to estimate a composite indicator of economic activity (CIEA) for Uganda. Working Paper BOUWP/11/11. Bank of Uganda, Kampala

Aron J, Muellbauer J, and Sebudde R (2015) Inflation forecasting models for Uganda: is mobile money relevant? CSAE Working Paper WPS/2015-17. Centre for the Study of African Economies: University of Oxford

Bank of Uganda (2015) Annual Supervision Report 2015/2016", Issue No. 6, Bank of Uganda: Kampala

Bank of Uganda (2016) Annual Report 2015/2016. Bank of Uganda, Kampala

Chibba M (2009) Financial inclusion, poverty reduction and the millennium development goals. Eur J Dev Res 21(2):213-230

Elliot G, Rothernberg TJ and Stock JH (1996) Efficient tests for an autoregressive unit root. Econometrica, 64(4):813-836.

EPRC (2013) Uganda 2013 FinScope III Survey Report: Unlocking Barriers to Financial Inclusion. Economic Policy Research Centre, Kampala

Evans DS, Pirchio A (2014) An empirical examination of why mobile money schemes ignite in some developing countries but flounder in most. Rev Netw Econ 13(4):397-451

Hamilton JD (1994) Time series analysis. Princeton university press, Princeton

Islam A, Muzi S, Meza JLR (2017) Does mobile money use increase firms' investment? Evidence from Enterprise surveys in Kenya, Uganda, and Tanzania. Small Bus Econ. https://doi.org/10.1007/s11187-017-9951-x

Johansen S (1988) Statistical analysis of cointegration vectors. J Econ Dyn Control 12:231-254 
Kamukama N, Tumwine S (2012) Mobile money services: a liquidity threat to Uganda's commercial banks. African Journal of Accounting, Economics, Finance and Banking Research 8(8):33-46

Keynes JM (1936) The general theory of employment, interest and money. Brace and company, Harcourt: New York, NY Kim S, Roubini N (2000) Exchange rate anomalies in the industrial countries: a solution with a structural VAR approach. J Monet Econ 45(3):561-586

Lutkepohl H (2005) New introduction to multiple time series analysis. Springer: Berlin, Heidelberg, New York

Lwanga MM, Adong A (2016) A pathway to financial inclusion: mobile money and household saving behavior in Uganda, Research Series No. 127. Economic Policy Research Centre, Kampala

Mawejje J (2019) Financial inclusion, shocks and coping strategies: survey evidence from Uganda. Afr J Econ Manag Stud. https://doi.org/10.1108/AJEMS-10-2018-0325

Mehrotra, A. and Yetman A. (2015) Financial inclusion - issues for central banks. BIS quarterly review. Bank for International Settlements: Basel

Munyegera GK, Matsumoto T (2018) ICT for financial access: Mobile money and the financial behaviour of rural households in Uganda. Rev Dev Econ 22(1):45-66

Nampewo D, Opolot J (2016) Financial innovations and money velocity in Uganda. Afr Dev Rev 28(4):371-382

Nampewo D, Tinyinondi GA, Kawooya DR, Ssonko GW (2016) Determinants of private sector credit in Uganda: the role of mobile money. Financial Innovation 2(13):1-16

Ndirangu L, Nyamongo EM (2015) Financial innovations and their implications for monetary policy in Kenya. J Afr Econ 24(AERC Supplement 1):i46-i71

Opolot J, Nampewo D, Ntumwa CA, Nyanzi S (2015) Financial Architecture and the Monetary Policy Transmission Mechanism in Uganda. Working Paper 02/2013. Bank of Uganda, Kampala

Riley E (2018) Mobile money and risk sharing against village shocks. J Dev Econ 135:43-58

Sahay R, Čihák M N'Diaye P, Barajas A, Mitra S, Kyobe A, Mooi YN, and Yousefi SR (2015) Financial inclusion: can it meet multiple macroeconomic goals? IMF staff discussion note SDN/15/17. International Monetary Fund: Washington, DC

Sekabira H, Qaim M (2017) Mobile money, agricultural marketing, and off-farm income in Uganda. Agric Econ 48(5):597-611

Simpasa A, Gurara D (2012) Inflation Dynamics in selected East African countries: Ethiopia, Kenya, Tanzania and Uganda. AFDB Brief 2012. African Development Bank, Abidjan

Ssonko GW (2011) Status of mobile money services in Uganda: an exploratory study. Working paper 08/11. Bank of Uganda, Kampala

Tumusiime-Mutebile E (2015) Mobile Money and the Economy, Opening Remarks by Prof. Emmanuel Tumusiime-Mutebile Governor, Bank of Uganda at workshop on the Economics of Mobile Money. International Growth Centre, Kampala

Weil D, Mbiti I and Mwega F (2012) The implications of innovations in the financial sector on the conduct of monetary policy in East Africa, Working Paper 12/0460. International Growth Centre

World Bank (2017). Step by step: Let's solve the finance puzzle to accelerate growth and shared prosperity. Uganda Economic Update, Eighth Edition: Washington DC

\section{Publisher's Note}

Springer Nature remains neutral with regard to jurisdictional claims in published maps and institutional affiliations.

\section{Submit your manuscript to a SpringerOpen ${ }^{0}$ journal and benefit from:}

- Convenient online submission

- Rigorous peer review

- Open access: articles freely available online

- High visibility within the field

- Retaining the copyright to your article

Submit your next manuscript at $\mathbf{s p r i n g e r o p e n . c o m ~}$ 